\title{
GAMBARAN PENGETAHUAN TENTANG STUNTING PADA IBU YANG MEMILIKI BALITA USIA 2-5 TAHUN DI DESA BUAHAN KAJA GIANYAR
}

\author{
Kadek Sri Ariyanti ${ }^{1,2}$, Rini Winangsih ${ }^{1,2}$, Genoveva Bili ${ }^{1,2}$ \\ ${ }^{1}$ Program Studi Diploma III Kebidanan, ${ }^{2}$ STIKES Advaita Medika Tabanan \\ Korespondensi penulis: ariyanthi.midwife@gmail.com
}

\begin{abstract}
Abstrak
Latar belakang: Stunting merupakan salah satu permasalahan balita yang harus mendapat perhatian khusus. Tingginya angka kejadian stunting pada balita dipengaruhi oleh berbagai faktor salah satunya adalah pengetahuan yang kurang tentang stunting.

Tujuan: Mengetahui gambaran pengetahuan tentang stunting pada ibu yang memiliki balita usia 25 tahun di Desa Buahan Kaja Gianyar.

Metode: Jenis penelitian ini adalah deskriptif dengan rancangan cross-sectional. Penelitian ini dilakukan di Desa Buahan Kaja Gianyar, pada Bulan Juli 2021 dengan jumlah sampel sebanyak 23 orang. Teknik pengambilan sampel dengan cara total sampling. Instrumen yang digunakan adalah kuesioner yang diberikan secara online. Analisis data menggunakan analisa univariat yang menghasilkan distribusi frekwensi variabel.

Hasil: Sebagian besar responden memiliki pengetahuan yang baik tentang stunting, yaitu sebesar $80 \%$.

Simpulan: Gambaran pengetahuan tentang stunting pada ibu yang memiliki balita usia 2-5 tahun di Desa Buahan Kaja Gianyar sebagian besar dalam katagori baik.
\end{abstract}

Kata kunci : Ibu Balita, Pengetahuan, Stunting

\section{Pendahuluan}

Kejadian balita pendek atau stunting merupakan salah satu masalah gizi yang dihadapi di dunia khususnya di Negara berkembang seperti Indonesia. Menurut WHO (World Health Organization) stunting disebabkan oleh beberapa faktor diantaranya asupan energi dan protein, serta penyakit infeksi sebagai faktor langsung. Pemberian ASI eksklusif, jenis dan frekuensi pemberian MP-ASI, status imunisasi, pekerjaan dan tingkat pendidikan orang tua serta status ekonomi keluarga merupakan faktor tidak langsung. Permasalahan gizi disebabkan oleh penyebab langsung seperti asupan makanan yang tidak adekuat dan penyakit infeksi. Sedangkan penyebab tidak langsung permasalahan gizi adalah masih tingginya kemiskinan, rendahnya sanitasi lingkungan ketersediaan pangan yang kurang, pola asuh yang kurang baik dan pelayanan kesehatan yang belum optimal (Kemenkes RI, 2018).

Data prevalensi balita stunting yang dikumpulkan World Health Organization (WHO), menunjukkan bahwa Indonesia termasuk ke dalam negara ketiga dengan prevalensi tertinggi di regional Asia Tenggara / South-East Asia Regional (SEAR) (WHO, 2010). Rata-rata prevalensi balita stunting di Indonesia tahun 2005-2017 adalah $36,4 \%$. Kejadian balita stunting (pendek) merupakan masalah gizi utama yang dihadapi Indonesia. Berdasarkan data Pemantauan Status Gizi (PSG) selama tiga tahun terakhir, pendek memiliki prevalensi tertinggi dibandingkan dengan masalah gizi lainnya seperti gizi kurang, kurus dan gemuk. Prevalensi balita pendek mengalami peningkatan dari tahun 2016 yaitu 27,5\% 
menjadi 29,6\% pada tahun 2017 (WHO, 2010).

Data Provinsi Bali menunjukan angka kejadian stunting yang masih cukup tinggi. Kabupaten Gianyar tahun ini masih menjadi fokus pemerintah Provinsi Bali dalam menuntaskan stunting. Hal ini tidak terlepas dari angka prevalensi stunting di Kabupaten Gianyar, yaitu sebesar 40,9\% (Riskesdas, 2013). Berdasarkan data Dinas Kesehatan Kabupaten Gianyar, ada 10 desa di Kabupaten Gianyar yang memiliki angka kejadian stunting yang cukup tinggi antara lain: Desa Lebih, Siangan, Lodtunduh, Singakerta, Sanding, Manukaya, Pupuan, Taro, Kedisan dan Bresela. 10 desa ini kemudian menjadi prioritas penanganan stunting hingga tahun 2020. Berdasarkan latar belakang di atas, peneliti melakukan penelitian dengan judul "gambaran pengetahuan tentang stunting pada ibu yang memiliki balita usia 2-5 tahun di Desa Buahan Kaja Gianyar.

\section{Metode Penelitian}

Penelitian ini menggunakan metode deskriptif kuantitatif dengan pendekatan cross-sectional, dengan tujuan utama dari penelitian ini adalah untuk menggambarkan suatu keadaan secara obyektif yang dilakukan hanya satu kali terhadap sekumpulan obyek dalam jangka waktu tertentu (Sugiyono, 2017).

Penelitian ini dilakukan di Desa Buahan Kaja Gianyar pada bulan Juni 2021. Sampel penelitian ini adalah ibu yang memiliki balita usia 2-5 tahun di Desa Buahan Kaja Payangan Gianyar dengan jumlah 23 orang. Teknik sampling yang digunakan dalam penelitian ini adalah total sampling. Instrumen yang digunakan dalam penelitian ini adalah kuesioner yang disebarkan secara online melalui google form. Analisa data yang digunakan adalah analisa univariat yang menghasilkan distribusi frekwensi karakteristik responden antara lain: umur, pekerjaan, paritas, penghasilan, umur bayi, serta mendistribusikan gambaran pengetahuan ibu tentang stunting.

\section{Hasil dan Pembahasan}

Tabel 1. Distribusi frekwensi karakteristik responden

\begin{tabular}{lcc}
\hline \multicolumn{1}{c}{ Karakteristik responden } & Frekuensi (f) & Presentase (\%) \\
\hline Umur & 7 & \\
$<20$ tahun & 9 & 30,4 \\
$20-35$ tahun & 7 & 39,2 \\
$>35$ tahun & 23 & 30,4 \\
Total & & 100 \\
\hline Pekerjaan & 10 & \\
Bekerja & 13 & 43,5 \\
Tidak bekerja & 23 & 56,5 \\
Total & & 100 \\
\hline Paritas & 12 & \\
1 & 9 & 52,2 \\
2 & 2 & 39,2 \\
3 & 23 & 8,6 \\
Total & & 100 \\
\hline Penghasilan & 14 & \\
$<$ Rp.2.000.000,00 & 9 & 60,8 \\
$>$ Rp.2.000.000,00 & 23 & 39,2 \\
Total & & 100 \\
\hline Umur Bayi & 7 & \\
2 tahun & 9 & 30,4 \\
3 tahun & 4 & 39,1 \\
4 tahun & 3 & 17,4 \\
5 tahun & 23 & 13,1 \\
Total & & 100 \\
\hline
\end{tabular}


Tabel 2. Gambaran Pengetahuan Ibu Balita tentang Stundting di Desa Buahan Kaja Gianyar

\begin{tabular}{lcc}
\hline \multicolumn{1}{c}{ Pengetahuan Ibu } & Frekuensi (f) & Persentase (\%) \\
\hline Baik & 19 & 83 \\
Cukup & 4 & 17 \\
Kurang & 0 & 0 \\
\hline Total & 23 & 100 \\
\hline
\end{tabular}

Dari Tabel 1 di atas dapat diketahui bahwa sebagian besar responden berumur 2035 tahun, yaitu sebanyak 39,2\%. Dari segi pekerjaan, sebagian besar responden tidak bekerja, yaitu sebanyak 56,5\%. Dapat diketahui pula sebagian besar responden memiliki paritas 1, yaitu sebanyak 52,2\%. Penghasilan keluarga sebagian besar $<$ Rp.2.000.000,00. Sebagian besar responden memiliki balita usia 3 tahun, yaitu sebanyak $39,1 \%$.

Dari Tabel 2 di atas dapat diketahui bahwa sebagian besar responden memiliki pengetahuan yang baik tentang stunting, yaitu sebanyak 83\%. Menurut Notoadmojo (2019), umur mempengaruhi daya tangkap dan pola pikir seseorang. Dengan bertambahnya umur seseorang, maka daya tangkap dan pola pikirnya akan lebih berkembang, sehingga pengetahuan yang diperolehnya pun semakin membaik.

Menurut Notoadmojo (2012), semakin tua umur seseorang maka proses perkembangan mentalnya semakin baik. Umur sangat berpengaruh pada pengetahuan. Umur yang cukup memiliki pola pikir dan pengalaman yang matang, sehingga pengetahuan yang diperolehnya semakin baik.

Menurut Notoadmojo (2019), Pengetahuan muncul ketika seseorang menggunakan akal budinya untuk mengenali benda atau kejadian tertentu yang belum pernah dilihat atau dirasakan sebelumnya. Pengetahuan adalah informasi yang telah dikombinasikan dengan pemahaman dan potensi untuk menindaki yang lantas melekat di benak seseorang. Pada umumnya pengetahuan memiliki kemampuan prediktif terhadap sesuatu sebagai hasil pengenalan atas suatu pola. (Notoadmojo, 2019).

Menurut George F. Kneller yang dikutip oleh Siswoyo dkk, (2017), pendidikan dapat dipandang dalam arti luas dan teknis. Dalam arti luas pendidikan menunjuk pada suatu tindakan atau pengalaman yang mempunyai pengaruh yang berhubungan dengan pertumbuhan atau perkembangan jiwa, watak, atau kemampuan fisik individu. Dalam arti teknis, pendidikan adalah proses dimana masyarakat melalui lembagalembaga pendidikan (sekolah, perguruan tinggi atau lembaga lainnya) dengan sengaja mentransformasikan warisan budayanya, yaitu pengetahuan, nilai-nilai keterampilanketerampilan dan generasi-generasi.

Pekerjaan orang tua mempunyai andil yang besar dalam masalah gizi. Pekerjaan orang tua berkaitan erat dengan penghasilan keluarga yang mempengaruhi daya beli keluarga. Keluarga dengan pendapatan yang terbatas, besar kemungkinan kurang dapat memenuhi kebutuhan makanannya secara kualitas dan kuantitas. Peningkatan pedapatan keluarga dapat berpengaruh pada susunan makanan. Pengeluaran yang lebih banyak untuk pangan tidak menjamin lebih beragamnya konsumsi pangan seseorang. Pendapatan keluarga yang memadai akan menunjang tumbuh kembang anak, karena orangtua dapat menyediakan semua kebutuhan anak baik primer maupun sekunder (Soetjiningsih,2018).

Lingkungan merupakan salah satu faktor yang mempengaruhi pengetahuan seseorang. Lingkungan memberikan pengaruh pertama bagi seseorang, dimana seseorang dapat mempelajari hal-hal yang baik dan juga halhal yang buruk tergantung pada sifat kelompoknya. Dalam lingkungan seseorang akan memperoleh pengalaman yang akan berpengaruh pada cara berfikir seseorang.

Sosial budaya dan informasi memiliki pengaruh yang kuat terhadap pengetahuan ibu tentang stunting. Seseorang memperoleh suatu kebudayaan dalam hubungannya dengan orang lain, karena hubungan ini seeorang mengalami suatu proses belajar dan 
memperoleh suatu pengetahuan. Informasi akan memberikan pengaruh pada pengetahuan seseorang. Meskipun seseorang memiliki pendidikan yang rendah tetapi jika mendapatkan informasi yang baik dari berbagai media misalnya $\mathrm{TV}$, radio atau surat kabar maka hal itu akan dapat meningkatkan pengetahuan seseorang.

Pengalaman juga merupakan salah satu factor yang memiliki andil yang besar terhadap pengetahuan ibu tentang stunting. Pengalaman merupakan guru yang terbaik. Pepatah tersebut dapat diartikan bahwa pengalaman merupakan sumber pengetahuan, atau pengalaman itu suatu cara untuk memperoleh kebenaran pengetahuan. Oleh sebab itu pengalaman pribadi pun dapat digunakan sebagai upaya untuk memperoleh pengetahuan. Hal ini dilakukan dengan cara mengulang kembali pengalaman yang diperoleh dalam memecahkan permasalahan yang dihadapi pada masa lalu (Notoatmodjo,2018).

\section{Simpulan}

Gambaran pengetahuan tentang stunting pada ibu yang memiliki balita usia 2-5 tahun di Desa Buahan Kaja Gianyar sebagian besar dalam katagori baik yaitu sebanyak $80 \%$.

\section{Referensi}

Anwar dkk. 2017. Stunting. Yogyakarta: Nuha Medika

Catur Baharudin. 2018. Faktor Stunting. Yogyakarta: Nuha Medika.

Depkes RI. 2018. Angka Kejadian Stunting di Indonesia.

Hadijah, 2018. Ilmu tentang stunting Yogyakarta Salemba Medika.

Kemenkes. 2016. Asuhan Kebidanan Balita. Yogyakarta: Nuha Medika.

Kemenkes. RI. 2018. Asuhan Kebidanan Balita. Yogyakarta: Nuha Medika

Khomsan. 2018. Stunting. Jakarta: Salemba Medika.

MCN, 2018. Stunting. Jakarta: Salemba Medika.

Notoatmodjo, 2017. Metodelogi Penelitian. Jakarta: Salemba Medika.
Siswoyo dkk. 2017. Pengetahuan stunting Jakarta : Salemba Medika

Soetjiningsih. 2018. Metodelogi Penelitian. Jakarta: Salemba Medika

Siswoyo, dkk. 2017. Faktor Stunting. Yogyakarta : Nuha Medika.

Sugiyono. 2017. Metodelogi Penelitian Jakarta: Salemba Medika.

Trihono, dkk. 2017. Kejadian Stunting Di Indonesia. Jakarta : Salemba Medika

Wibowo, Adi. 2017. Kejadian Stunting Di Indonesia. Jakarta : Salemba Medika.

Wahyudi. 2018. Metodelogi Penelitian. Yogyakarta: Nuha Medika 